\title{
Basic Study on the Vibration Analysis of Middle Ear
}

\author{
$\bigcirc$ 学 谷 康 (阪府大院) 正 新谷 篤彦 (阪府大) 正 伊藤 智博 (阪府大) \\ Yasushi TANI, Graduate School of Engineering, Osaka Pref. Univ., 1-1 Gakuen-cho, Naka-ku, Sakai-shi, Osaka \\ Atsuhiko SHINTANI, Osaka Pref. Univ. Tomohiro ITO, Osaka Pref. Univ.
}

\section{1 緒言}

ヒトは空気の振動を耳の内部で捕らえることにより音 を把握することができる. その際, 鼓膜, 耳小骨などの耳 の各器官がどのように振動し，それらが音の聞こえ方に どのように影響を与えているかは振動学的には十分検討 されていない. 補聴器や携带電話, 音響機器などの性能 向上を目的として，耳の音を捕らえるメカニズムを検討 する. 本研究では, 鼓膜を周辺固定の円形の弾性膜, 耳 小骨を 2 自由度系としてモデル化し，様々な音圧の入力 を与えることにより，系の固有振動数や振動挙動等につ いて検討する。

\section{2 解析モデル}

ヒトの鼓膜を周辺固定の円形の弾性膜，耳小骨を 2 自 由度系としてモデル化する (Fig.1). ただし，耳小骨は鼓 膜の中心部に接しているものと仮定している.

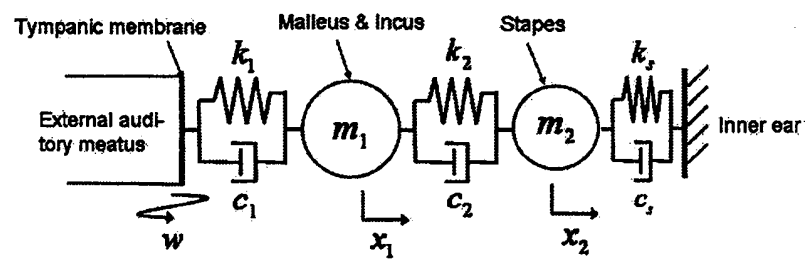

Fig. 1: Analytical model of middle ear

\section{3 運動方程式}

ツチ骨は鼓膜の中心部と接合しており，鼓膜の振動が 変位励振としてツチ骨に作用し，ツチ骨とキヌタ骨は一 体となっていると仮定した. 鼓膜, ツチ骨・キヌタ骨, ア ブミ骨の運動方程式はそれぞれ，

$$
\begin{aligned}
& \mu \frac{\partial^{2} w}{\partial t^{2}}+c \frac{\partial w}{\partial t}-P\left(\frac{\partial^{2} w}{\partial r^{2}}+\frac{1}{r} \frac{\partial w}{\partial r}+\frac{1}{r^{2}} \frac{\partial^{2} w}{\partial \theta^{2}}\right)=Z(t) \\
& m_{1} \ddot{x}_{1}+c_{1}\left\{\dot{x}_{1}-\dot{w}\left(r_{0}, \theta_{0}, t\right)\right\}+c_{2}\left(\dot{x}_{1}-\dot{x}_{2}\right) \\
& \quad+k_{1}\left(x_{1}-w\left(r_{0}, \theta_{0}, t\right)\right)+k_{2}\left(x_{1}-x_{2}\right)=0 \\
& m_{2} \ddot{x}_{2}+c_{2}\left(\dot{x}_{2}-\dot{x}_{1}\right)+c_{s} \dot{x}_{2} \\
& \quad+k_{2}\left(x_{2}-x_{1}\right)+k_{2} x_{2}=0
\end{aligned}
$$

で与えられる.ここで， $\mu$ : 鼓膜の単位面積当たりの質量, $c$ : 鼓膜の减衰係数, $P$ : 張力, $m_{1}$ : ツチ骨とキヌタ骨の 質量, $m_{2}$ : アブミ骨の質量, $k_{1}$ : 鼓膜とツチ骨間のばね 定数, $k_{2}$ : ツチ骨・キヌタ骨とアブミ骨間のばね定数, $k_{s}$ : アブミ骨と内耳間のばね定数, $c_{1}$ ：鼓膜とツチ骨間の減 衰係数, $c_{2}$ : ツチ骨・キヌタ骨とアブミ骨間の減衰係数, $c_{s}$ : アブミ骨と内耳間の减衰係数である.さらに $Z(t)$ は 音圧 $Z_{0}[\mathrm{~dB}]$ を用いて, 鼓膜の単位面積当たりに働く力 $10^{Z_{0} / 20} \times 2 \times 10^{-5}\left[\mathrm{~N} / \mathrm{m}^{2}\right]$ の大きさで作用するものとす る.

\section{4 数值シミュレーション}

外耳道より外力 $Z(t)$ を与え, 様々な音圧におけるツチ 骨及びキヌタ骨の変位 $x_{1}$, アブミ骨の変位 $x_{2}$ の振動挙動 について検討した. 外力は鼓膜全体に一様に作用するもの とし，ヒトの日常会話は約 $1000[\mathrm{~Hz}]$ であるので, ここで は $1000[\mathrm{~Hz}]$ の正弦波入力で $60[\mathrm{~dB}], 80[\mathrm{~dB}], 180[\mathrm{~dB}]$ の 音圧を与えた時の耳の振動挙動をそれぞれ Fig.2〜Fig.4 に出す，各音圧において，左図はツチ骨及びキヌタ骨，右 図はアブミ骨の振動を示している.

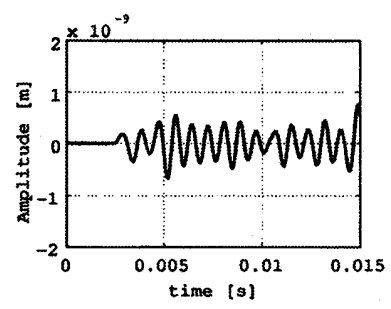

(a) Malleus \& Incus

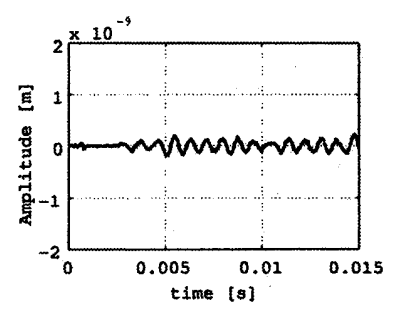

(b) Stapes
Fig. 2: Time responce of middle ear $(60 \mathrm{~dB})$

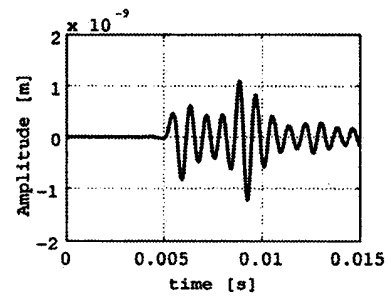

(a) Malleus \& Incus

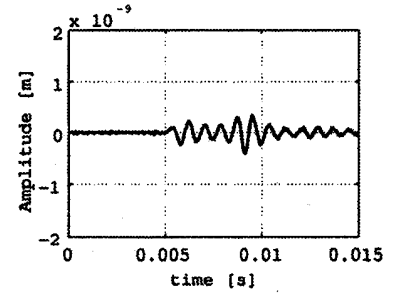

(b) Stapes
Fig. 3: Time responce of middle ear $(80 \mathrm{~dB})$

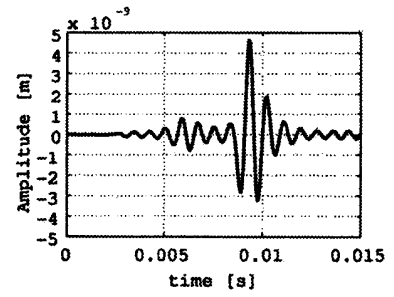

(a) Malleus \& Incus

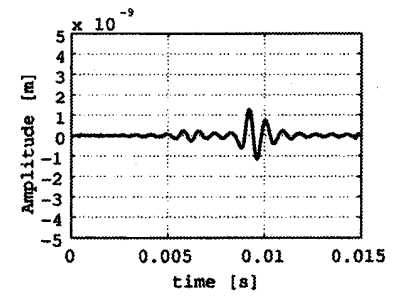

(b) Stapes
Fig. 4: Time responce of middle ear $(180 \mathrm{~dB})$

$60[\mathrm{~dB}], 80[\mathrm{~dB}]$ ではツチ骨・キヌタ骨の振幅は, アブ ミ骨の振幅の約 2 倍となっており, 和田らの結果と一致 している. 詳細については当日報告する.

\section{参考文献}

1. 小池, 和田, 小林, 日本音響学会誌, Vol.52, No.9, pp.695-702 (1996). 